\title{
Pigeon-breeder lung disease
}

INSERM

\section{Source}

INSERM. (1999). Orphanet: an online rare disease and orphan drug data base. Pigeonbreeder lung disease. ORPHA:99908

Pigeon-breeder's lung disease, also called bird fanciers lung, is a hypersensitivity pneumonitis (see this term) induced by inhalation of bird derived-proteins. Presentation can be acute with chills, cough, fever, shortness of breath, chest tightness usually resolving within $24 \mathrm{~h}$ after cessation of antigen exposure, sub-acute with cough and dyspnea over several days to weeks, whereas chronic form results in breathlessness, coughing, lack of appetite and weight loss. 